\title{
Strandinger ved Rømø i 1700-tallet
}

\author{
af BERT KeLM
}

Strandinger var i ældre tid en af de værste farer, som lurede på søfarten. For søfolk, skibsredere og købmænd stod liv og ejendom på spil, for befolkningen langs kysten kunne strandinger give store indtægter $\mathrm{i}$ bjærgeløn. Bert Kelm, Hamborg/Kromose, har undersøgt strandingerne på Rømø i 1700-tallet. Gennem en række dramatiske strandingsepisoder belyser han nogle af søfartshistoriens skyggesider og viser, hvordan strandingssagerne blev administreret på en ø, som var delt mellem slesvigsk og kongerigsk forvaltning.

I sejlskibstiden, inden motorkraften kom til hjælp, var skibenes færd på verdens have alene afhængig af vejret, der dengang ikke kunne forudsiges. Navigationen uden vore dages ekkolod og radar krævede i det mindste fra tid til anden klar sigt til himlen eller en kyst for at bestemme skibets position og videre kurs. Og der var kun begrænsede muligheder for at indvirke på kursens retning i en storm. Derfor var strandinger helt ind $i$ vores århundrede en af de værste farer, som lurede på skibsfarten.

Kystbefolkningen havde derimod chancen for en ekstra indtjening, når et skib strandede. Vistnok er det overdrevet, når det fortælles, at folk har bedt om "strandens velsignelse «. Og historier om, at man lod heste løbe langs stranden med en fakkel bundet til halen for at vildlede skibene, synes at være rent opspind. Men det var vist ikke uden grund, at der skrives $i$ den kongelige forordning af 1705 angående strandinger (fig. 2): "... (hvem) forføre(r) den Sejlende og bringer ham til Ulykke eller Fare, skal straffes på Livet «. Denne forordning har $\mathrm{i}$ øvrigt været grundlag for en tilpasning af Den Danske Lovs 4. bog om søretten og derved forbedret retssikkerheden ved strandingerne.

Oftest var strandinger forbundet med menneskelige tragedier. $\mathrm{Og}$ for kystbefolkningen var det en selvfølgelig pligt at satse eget liv for at redde de strandede søfolk. Overlevende blev plejet på bedstmulige måde, og døde begravedes kristeligt på egnens kirkegård. 


\section{Kildematerialet}

Ved strandingsgods drejede det sig ofte om store værdier. Derfor forbeholdt staten sig strandrettighederne, der fra 1600-tallets slutning blev bortforpagtet fortrinsvis til købmænd fra fastlandet. Disse forpagtere har igen underforpagtet strandretten til lokale folk, der kunne overvåge stranden og bjærge strandede skibe eller gods. Udover disse "interessenter" var en strandfoged lige som idag øvrighedens stedfortræder $\mathrm{i}$ alle strandsager på egnen. Senere $\mathrm{i}$ århundredet blev der dannet konsortier af fastlands- og Rømøfolk, strandfogeden inkluderet, der direkte kontraherede med myndighederne.

Selvfølgelig skulle alt strandingsgods, der ikke stammede fra hjemlandet, fortoldes. Derfor blev tolderen ofte indblandet i strandingssagerne. Og hvis et helt skib strandede, og varernes oprindelse var kendt, kom skipper og redere (dengang ofte et partnerskab), befragteren, forsikringen og den planlagte modtager af varerne med ind i sagsbehandlingen. Der var mange muligheder for strid og retssager! Det forklarer, at vi endnu i dag har mulighed for at følge en hel del strandinger fra hine tider gennem retskilderne og toldregnskaberne.

Grafikken på fig. 3 viser de kendte strandinger over mere end to århundreder. Undtaget er sager, hvor det drejer sig om strandet gods uden vrag. Præcis hvor mange strandinger der fandt sted ved Rømø i 1700-tallet, vides ej. Tingbøgerne fra de to tingsteder, hvor Rømø-sagerne blev behandlet, Ballum Birketing for den kongelige del (Sønderlandet) ${ }^{1}$ og Hviding Herreds Ting for den slesvigske del (Nørlandet), ${ }^{2}$ er nemlig kun delvis bevaret. For Ballum mangler tiden efter 1778, for Hviding Herred perioden før 1717 og enkelte år midt $\mathrm{i}$ århundredet. Indtil 1699, det forste forpagtningsår for Nørlandet, kendes en del strandingssager fra Haderslev Amtsregnskab, idet de indkasserede penge blev afleveret dér. For 1700-tallet mangler disse oplysninger på grund af forpagtningen, dvs. kun pagtbeløbet nævnes, og da strandingssagerne kun blev forhandlet ved tinget, når der var opstået en stridighed, mangler vi fyldestgørende oplysninger fra disse kilder. Først efter omkring 1740 indledes for Norlandet en systematisk behandling af strandingerne ved retten, forudsat at vragets og varernes oprindelse var kendt. List toldregnskaber ${ }^{3}$ fra toldstedets indretning i 1680 til ophævelsen i 


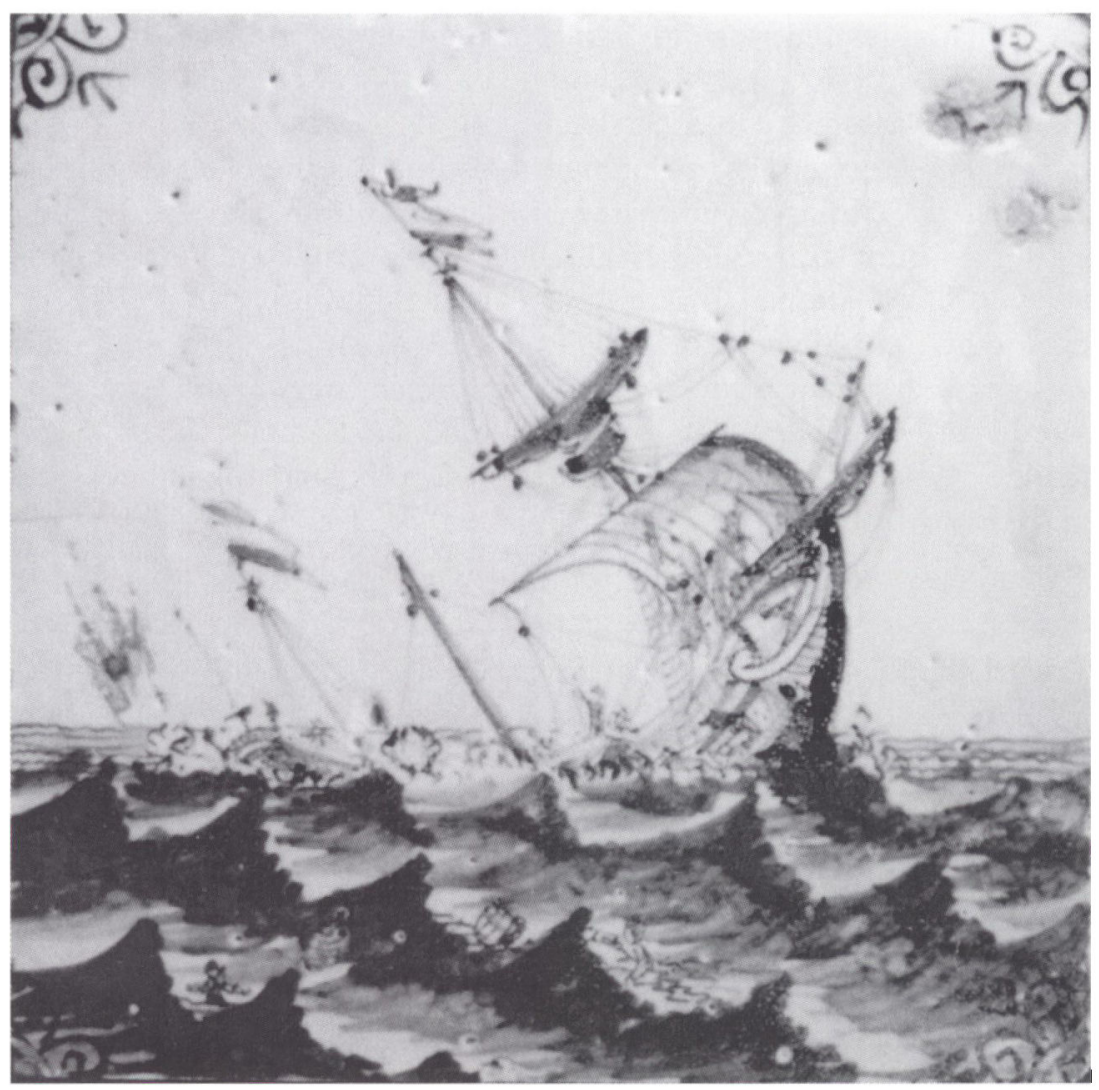

Fig. 1. Hollandsk flise med skibshavari som motiv.

1770erne er heller ikke fuldstændige. Men der findes såkaldte »anteignelser « for alle år, og man kan gå ud fra, at større strandingssager nævnes dér, når der var varer at fortolde. Nørlandet blev først lagt under List-toldstedet efter en forordning af 9.12.1727, og det varede vist nok endnu nogle år, før strandinteressenterne rettede sig efter denne regel.

Disse mangler i kilderne betyder, at oplysningerne i 1700-tallets første og sidste fjerdedel ikke er fyldestgørende, mens strandingerne $\mathrm{i}$ århundredets midte måske alle er med. Af de 28 kendte Rømø-strandinger fra 1700-tallet (tabelbilag 1) er kun 8 fra de to usikre perioder, først og sidst $i$ århundredet. Derfor må man antage, at der i alt er forekommet 35 til 40 skibsstrandinger ved Rømøs kyst i dette århun- 
drede. Påfaldende er en rolig tid i 1730erne og i modsætning hertil årene 1760 og 1767 med 4 hhv. 3 ulykker i løbet af en måned. Oktober måned optræder 11 gange på listen.

For 1800-tallet findes oplysninger dels fra Hviding Herreds tingbøger, dels fra en håndskreven samling af strandingssager, nedskrevet af Bunde Bundesen, der i 1900-tallets forste årtier var bådformand ved redningsstationen i Juvre. ${ }^{4}$ Til sammenligning viser grafikken $i$ fig. 3 også strandinger ved Sild, ${ }^{5}$ en $\emptyset$, der har en kyststrækning mere end dobbelt så lang som Rømø, og som ligger nogle km længere ud mod vest. Forskellen ses tydeligt i 1800 -tallet, mens der mangler mange Sild-strandinger fra århundredet forud i statistikken, f.eks. fra kysten ved List. $^{3}$

\section{Dybdeforhold}

Et spørgsmål er, hvorfor så mange skibe - 23 af de 28 - strandede ved Nørlandet, mens Sønderlandets folk for det meste måtte nøjes med strandingsgods. Kortet fig. 4 viser dybdeforholdene ud for Rømøs kyst. Mørke arealer ligger tørt ved springlavvandet eller højere. Den næste linie viser 2-m-dybden. På øens vestside drejer 2-m-linien mod nord mere og mere mod vest, og ved øens nordende strækker dette flak sig $6 \mathrm{~km}$ ud. Udover dybden spiller strømmen en meget stor rolle. Basisstrømmen går nordpå og forstærkes ved alle vindretninger mellem syd og vest. Kun ved nord- hhv. nordvestvind drejer strømmen mod syd. Det betyder, at Nørlandets flak virker som en fælde: Når sejlskibene ved vinde fra syd til vest har klaret List med dennes mindre flak, geråder de med vind og strøm fra syd på Nørlandets flak. Når man ved vinde fra nord til nordvest har klaret Horns rev, hænger man fast på Nørlandets flak nordfra, eller på »Knuderne«, Koresandets sydvestlige hjørne. Kun ved vinde fra vest til nordvest kan skibe uden motorkraft strande ved Sønderlandets kyst. Disse forhold fremgår allerede af Niels Hegelunds søkort fra 1689, hvor Nørlandets flak langt ud mod vest kaldes for "Jørgen Hansens Knude«.

I det følgende vil jeg fremdrage en række særligt interessante strandingshistorier fra 1700-tallet. På den måde er det muligt at kaste lys over datidens sejlskibsliv, handels- og retsforholdene og øboernes indblanding i sagerne. 


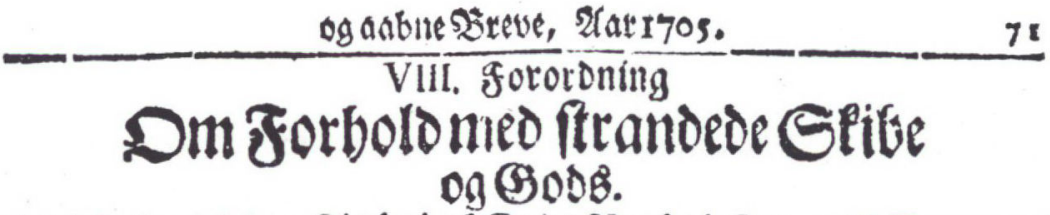

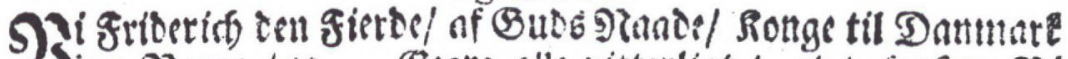

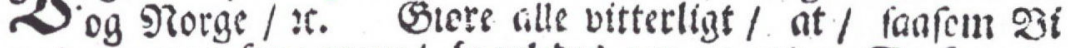

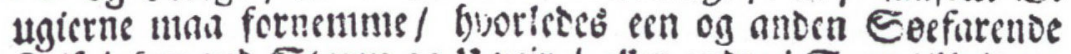
goll / fom ved Storm og liveje / eller snore $i$ Eoen tilfaloen= ic ulvelelige Sanosifer 7 fommer til at lioe Éfiobruo/ $\mathrm{eg}$ meo

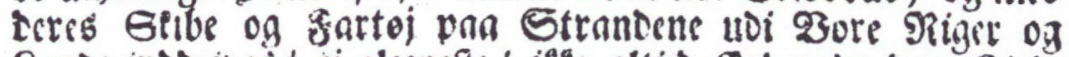

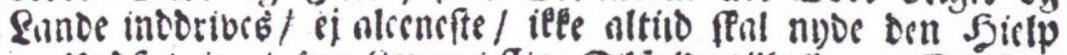

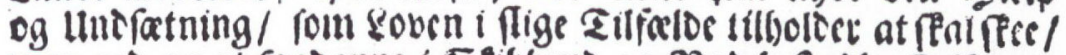
men eno og at frabanne i Stibbruo og Neo beftade gole Der foruben een og anden Dberlaft / Rouctj og Tyuerj af onte og u. Daxbife Dennifter f́mod Buos / Raturens og Dores Lov paa

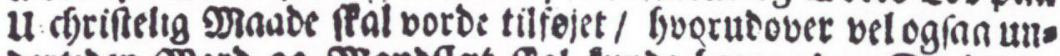
Dertiden moro og Manoflat ffal tunde beganes; Da / paa Dit be Goefarente / fom berefter lunce lomme til at libe Slibs brno utt 2oce Riger og lanoe/ tand oer nube beborig lund fat. ning og efrelie for fig/ og buis te meo fig forer / og onde eg bans nrtige Mennifer/ fom dennem uot fandonne u. Inelelige Tils falce enten paa een eller ancen Mante ville foge at brffadige / oct fra bintreb og affectete / habe 23ilfle aleenefte berves villet bave alle og enfoer 23 colonmenie/ frm bect og tilbolter paa de Sta.

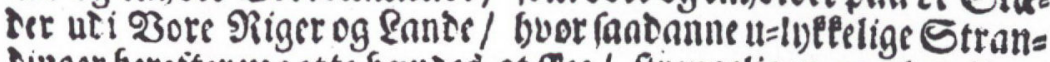
rinaer fereftermantte borlires at ffee / ftrengelinen og alvorligen erincret og ntuarst / at is fig/ fan bititenbuer tillonimer / efters

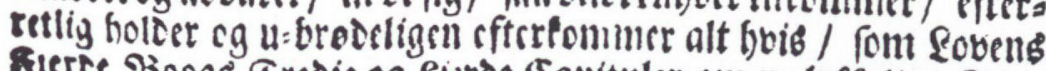
Eterce Bocgs Tredie cg Sirte Enpitulcr oul $\mathfrak{u}=$ Inelelige Sarn. belke I item om Eflubino og शुab byoer og befaler / nten for Gllbbruone goll og til Straffing Gliatpelie for Dennemt

foin

Fig. 2. Forste side af kongelig forordning 1705 om strandinger. 


\section{En kongelig spansk fregat »Princesse «} strander i 1716

Den 19. februar 1717 var Ballum tinget kaldt sammen for at behandle sagen om den kongelige spanske fregat "Princesse", der var strandet i januar 1716 ved Rømø Nørlands kyst. Desværre mangler Hviding Herreds tingbøger for oktober 1716, hvorfor strandingens detaljer ikke kendes. Men redningsaktionen var så stor en sag, at også Sønderlandets folk deltog i den. Derfor kom en såkaldt »Inquisitionssag « på dagsordenen på Ballum tinget, hvor fregattens (fig. 5) kaptajn udspurgte vidnerne fra Sønderlandet, om alle bjærgede materialer var bleven angivet på en række kvitteringer. Af disses indhold kan vi danne os et billede af sagen.

Der blev reddet 70 personer, hvilket blev betalt med 4 mark pr. person. Adskillige kanoner ("Stöcker") blev bjærget og bragt i land med vogn. Mange flag ("Svenske, Hollandske, Holstenske« m.v.) og vimpler såvel som sejl, træværk, kobberdele, 1 stol og klædestof fin-

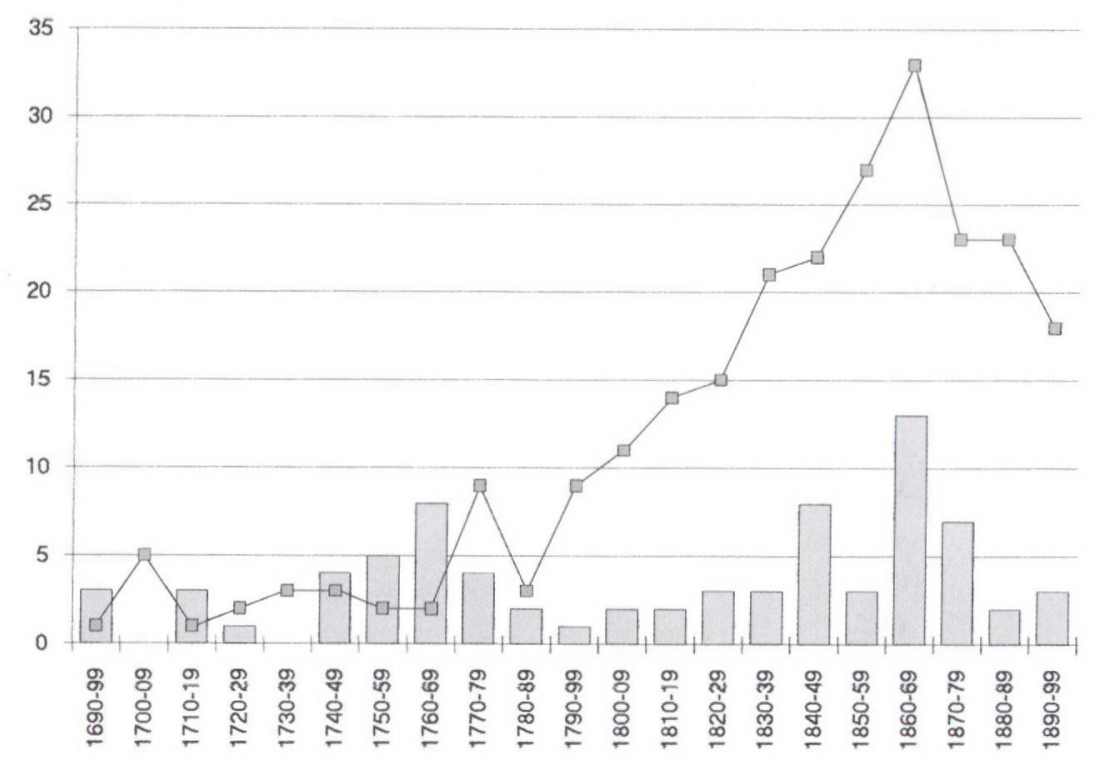

Fig. 3. Kendte strandinger ved Rømø og Sild i 1700-tallet. Søjlerne viser strandinger på Rømø, linjen strandinger på Sild. 
des oplistet. Et vidne oplyser, at noget krudt endnu lå hos en bonde i Juvre. Men alt i alt fik kaptajnen ikke meget ud af undersøgelsen.

I 1824 berettes, $^{6}$ at en spansk gesandt omkring 100 år før var omkommet ved Rømøs kyst sammen med familie og følge. Man kan vel formode, at det drejer sig om en af passagererne på »Princessens« rejse fra eller til en nordeuropæisk hovedstad.

\section{7 - Peder Holms strandingskup}

En stranding i 1717 har særlig interesse, fordi den belyser de mange problemer som fulgte med Rømøs daværende deling mellem den slesvigske del i nord og den kongerigske del i syd. Sagen behandles tre gange på Hviding Herreds ting, seks gange på Ballum ting og en gang på Fanøs birketing.

Søndag den 26. september 1717 opdages et vrag vest for »Knuds« drivende uden besætning. 5 både fra Fanø sejler derud, men de forlader vraget på grund af mørke uden at tage mere end nogle småting. Vraget driver efterhånden sydpå og når næste morgen ud foran Bollert sand, "omtrent $1 \mathrm{mil}$ (1852 m) fra landet, i vilde søe, på 14 foed vand, vinden norden og nordnordøst, med ebbe, som fører (vraget) sydvest i søen «. Nogle Nørlandsfolk sejler derud på Peder Præstes båd og lægger sig til vragets bagbordside. De har ordre fra herredsfogden om at føre vraget til Nørlandets havn ved Kongsmark. Peder Jørgensen er den første ombord. Der er "ingen skibsfolck «, vraget er »uden stormast, fockmast, ancker og tov og uden luger ... ganske spoleret $\ll$. Der er $2 \frac{1}{2}$ fod vand i skibet. Ballasten ligger i styrbord, og vraget hælder til siden.

Der kommer også to både fra Sønderlandet med 10 mand og lægger sig til styrbordsiden. Efterhånden sejler endnu 7 både fra Nørlandet derud, men da de får at vide, at folk ombord ikke vil have mere hjælp, vender de tilbage. På vraget enes Nørlands- og Sønderlandsfolk om, hvordan man skulle bringe det til Kongsmark: den sikreste vej ville være gennem Blådybet, der dengang dannede en sejlbar rende mellem Havsand og Rømø. Men det lykkes ikke. Vraget støder på grund ved lavvande og alle forlader det.

Om natten driver skibet længere sydpå og ind på Sønderlandets forstrand, hvor det sidder fast så tæet ved landet, at man ved lavvande kan gå ud til det. Skellet mellem øens to dele dannes af en række pæle tværs over stranden. Sønderlandets strandinteressenter anført af 
den 27-årige, meget dygtige skipper og handelsmand, senere landfoged og kirkeværge Peder Holm fra Tagholm, kommer til stranden og »tillader videre bjærgning mod løn«. Det lykkes først den 1 . oktober at få gjort vraget fri og slæbt ind til Havneby, hvor det ankommer den 4 . oktober. Nørlandsfolk vil have vraget ført videre til Kongsmark, men Peder Holm nægter at give skibet fri.

$\mathrm{Nu}$ begynder retssagen, første gang den 25. oktober ved Hviding Herreds ting. 11 mand fra Nørlandet og 14 fra Sønderlandet er stævnet. Deltagerne i den første aktion den 27. september er stort set enige om hvad der var hændt. Skibet var den dag stødt på grund i Nørlandets strandområde. Det bekræftes en anden tingdag, da 6 nye Nørlandsvidner er spurgt om det, der skete. Men på Peder Holm, der var på tinget på Sønderland-strandinteressenternes vegne, gør det ingen indtryk. Han siger, at man skal søge ham ved hans eget ting, i Ballum.

Sådan sker det, og den 12. november mødes parterne ved Ballum tinget. Dér optræder nu Peder Holm sammen med 10 bjærgere fra Sønderlandet. Fra Nørlandet er 6 mand stævnet. Og én fra Fanø er også med på Fannikernes vegne, fordi sagen begynder med deres krav om andel i det bjærgede. Men tinget afviser det, da Fanø-folkene havde forladt vraget og derved opgivet deres rettigheder.

Den 26. november fortsættes sagen. Nu har Sønderlandets strandinteressenter, Peder Holm, Søren Ambders (præstens søn), Mathias Nielsen og Peder Jørgensen, indsat en sagfører, "Sr.« Rutenström, der skal handle for dem. De samme personer som før er kaldt til tinge og afgiver nu en skriftlig beretning. Der er ikke noget nyt, men med advokatens hjælp behandles sagen igen den 10 . december, indtil den afgøres endeligt den 17. december. Peder Holm får ret og vraget forbliver ved Sønderlandet. Det har altid været en fordel, når man kan fremlægge et faktum!

\section{Nørlandets nye strandinteressenter}

I perioden fra denne store strandingssag og indtil 1745 hører vi kun om to vrag ved Sønderlandets strand. 1722 strides om et vrag, hvad der leder til slagsmål mellem interessenterne. Åbenbart har hovedforpagteren Winckler fra Hamborg (der samtidig har østersbankerne i pagt) ikke skaffet klare forhold for underforpagterne. 1742 strander en smakke fra Rendsborg, der bl.a. har enebær-brændevin med om 


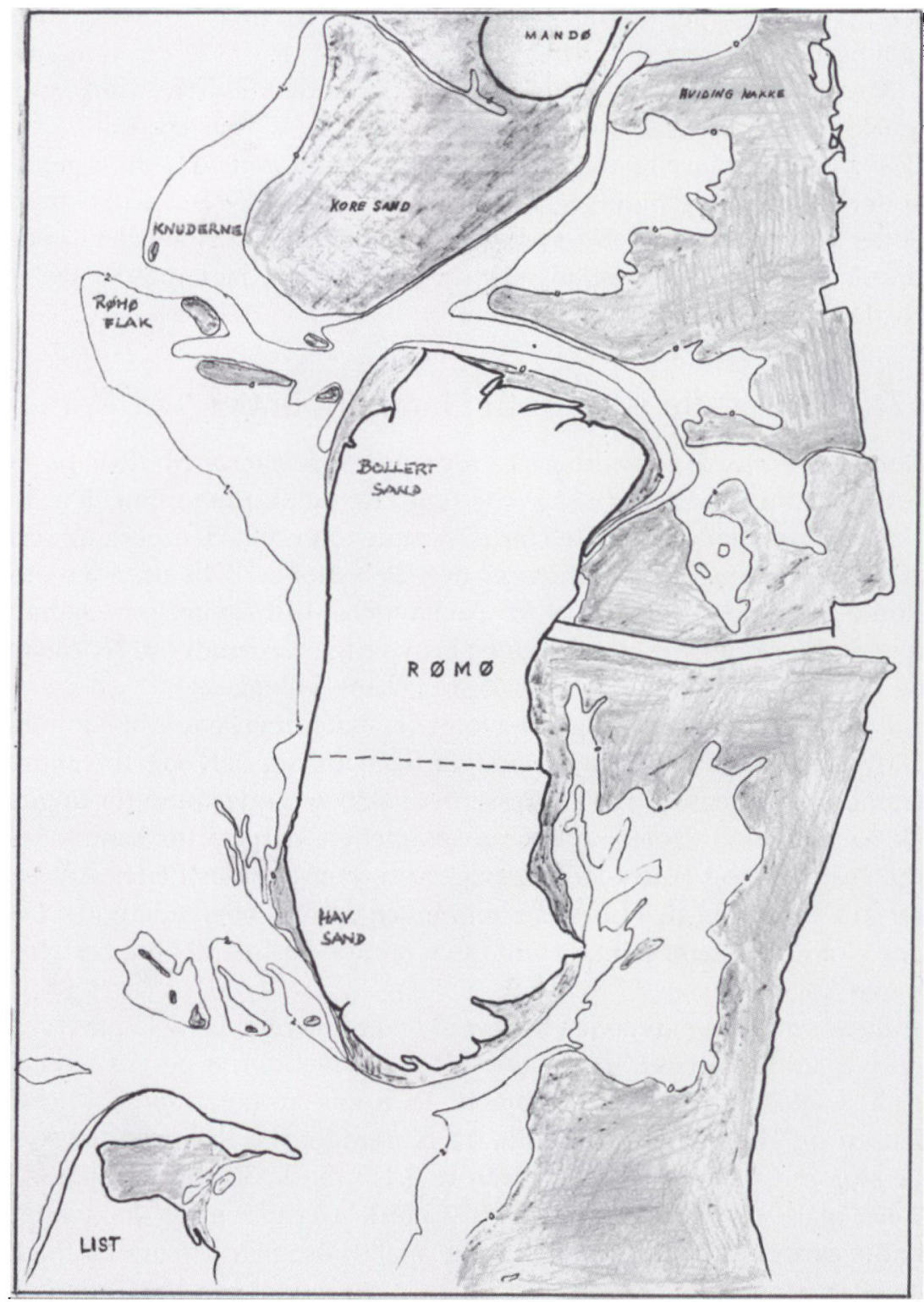

Fig. 4. Dybdeforholdene ved Romøs kyst $i$ dag. Mørklagte områder ligger på springlavvandets niveau eller højere. Den næste linje viser 2-meter dybden. 
bord. På Nørlandet straffes i løbet af disse årtier enkelte beboere for ulovlig færdsel ved stranden.

Men én ændring af pagtforholdene er påfaldende: Hovedforpagteren for Nørlandets strand, Anders Jebsen fra V. Vedsted, har siden 1727 nye underforpagtere, »interessenter «, på Rømø. Af i alt 6 mand er der 4 fra Sønderlandet, og 3 navne kender vi fra 1717-sagen, nemlig Peder Holm, Søren Ambders og Mathias Nielsen. Den fjerde er øens præst, siden 1733 Christian Neve. Man har vist lagt mærke til, at Nørlandets strand er mere lønsom.

\section{5 - turen fra ishavet til Hamborg ender ved Rømø}

Den næste større strandingssag forhandles den 6 . april 1746 på et »ekstraordinair« ting i Brøns, Hviding Herreds normale tingsted. Et skib med navnet "Het witte Hart « hjemmehørende i Hamborg og ført af skipper Hans Jacob Dahler, er den 20. oktober 1745 strandet ved Rømø Nørlands kyst, på vej fra Archangelsk til Hamborg. Et sådant uheld, der skete efter den lange og besværlige tur rundt om Nordkap og næsten hjemme (fig. 6, kurs 1), var ekstra beklageligt.

De nærmere omstændigheder omtales ikke, men en "Mr. Anthoni Gloy" fra Hamborg som "Mandatarius" for sig selv og tre andre Hamborg-købmænd, alle interessenter i skibet, møder frem for tinget. De to "Subconductores « af strandrettigheden, den fra for kendte Søren Ambders og Peder Holms svigersøn, kommandør Peder Andersen fra Kromose, skal bekræfte regningen for det bjærgede gods. Peder Holm selv kunne ikke være med; han døde kun to uger før retssagen.

Listen over de bjærgede varer er skrevet i november 1745 i nærværelse af tolder Roeder "på Listø巛. Alt er efterset, tørret og vurderet af i alt 9 takseringsmænd, deriblandt to Rømø-kommandører, Michel Jensen og Hans Hansen Tønnis fra Nørlandet. På listen findes som de største værdier 374 tønder tran til 8.415 mark, 307 tønder tjære til 2.456 mark og 39 fade talg til 5.282 mark. Derudover er der mange andre poster, bl.a. bjørneskind og hermelin. Brugbar skibsudrustning er også regnet med, nogle sejl og meget tovværk. I alt er værdien takseret til at være 21.029 mark eller lidt over 7.000 rigsdaler, en stor formue dengang.

Desværre er der ingen oplysninger om, hvor meget »interessenterne« og bjærgerne får. Men fra andre tilfælde kan man gætte på hen- 


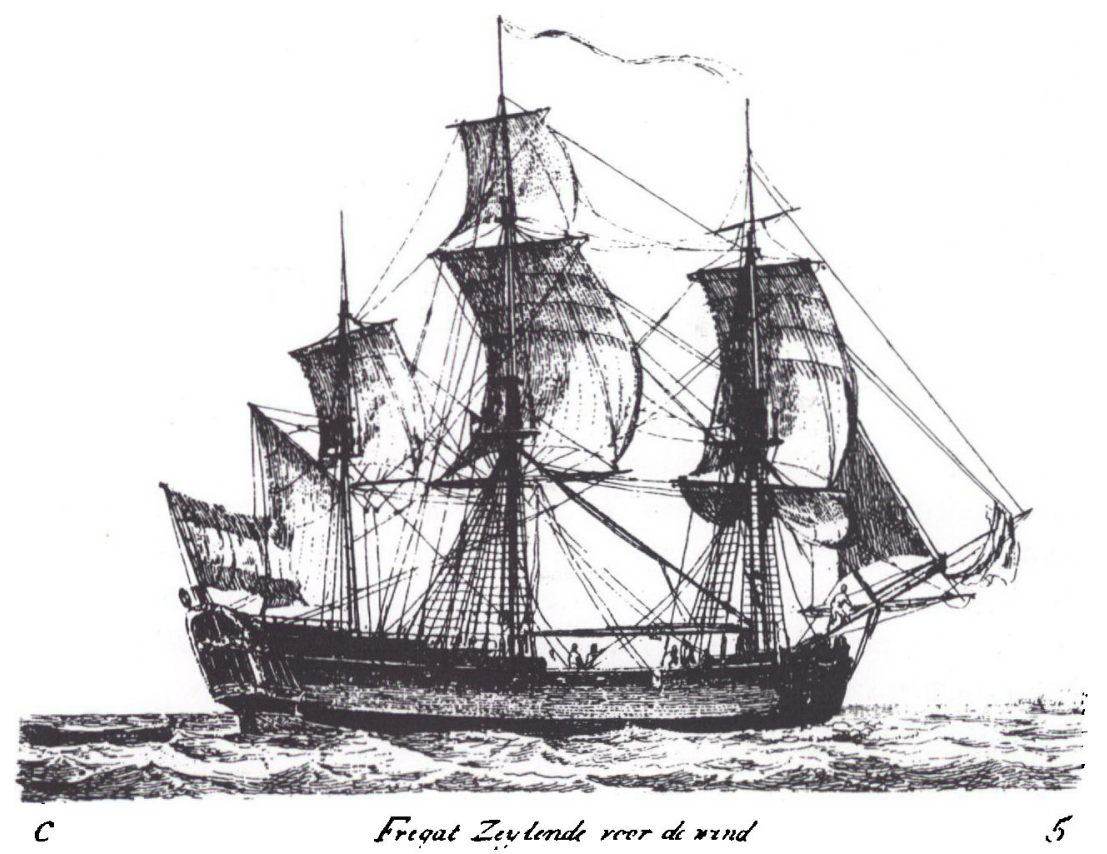

Fig. 5. Fregat. Gengivet efter C. Groenewegen: Verzameling van vier en tachtig stuks Hollandsche Schepen (Rotterdam 1789).

ved 2.000 rigsdaler. Ingen dårlig forretning! Skibets størrelse er heller ikke beskrevet $\mathrm{i}$ tingbogen. Varernes mængde og vægt, især antallet af tonder, peger på et skib af 60-80 såkaldte kommercelæster á ca. 2 tons, $\mathrm{i}$ den tid et mellemstort handelsskib.

\section{7 - strandet på vej fra Amsterdam til Bordeaux}

Det næste ekstrating samles i Brøns den 21. december 1747. Der forhandles om to strandinger, der næsten skete samtidigt. En skipper Hinrich Worms fra Hamborg fortæller »wehmütig « (skipperens beretning er skrevet på tysk) historien om skibets Odyssé. Tre-mast-hukkerten "Christiana" er sejlet fra Amsterdams red ved Texel den 22. november og ville derfra til Bordeaux, hvor der skulle lastes varer. Den 27.-29. november er der hård storm fra vestnordvest. Skibet, ellers "gut conditionirt", springer læk. Ikke engang med to pumper kan mandskabet holde hukkerten lens, og skipperen er nødsaget til at 
finde en havn. På grund af stormens modvind ligger skibet endnu ud for Hollands vestfrisiske øer, og ville så sejle ind $\mathrm{i}$ "Flie«, Zuidersøens ostlige sejlrende (fig. 6 kurs 2). Men om aftenen, allerede nær kysten (»under wallen «), blæser stormen så hårdt og nu fra sydvest, at skibet driver forbi indsejlingen. Næste morgen er stormen taget til. De kan ikke mere redde sig for vandet, "weder oben noch unten «, og må lede efter en anden havn for ikke at gå ned. Den 1. december er de nået til vest for Rømø og finder grund til ankring, 6 favn dyb, efter "viel Gefahr und Noth«. Om natten kl. 12 slår tunge søer pallerne fra bratspillen i stykker. Den næste dag, lørdag den 2. december, springer ankertovene, og hukkerten må i vedvarende storm sejles ind på Nørlandets strand. En kvart mil fra landet "oder sogenannten Dünen" (såkaldte klitter) sidder skibet fast og mandskabet kan vade i land. Da der ikke er håb om skibets redning, bjærger de sammen med nogle Rømø-folk (»Eingesessenen «) takkelage, tovværk og redskaber i land. Dette arbejde varer fem dage. Såvidt skipperens beretning.

Derefter læses skibsjournalen, ført af styrmand Tönnis Brinckmann fra Vegesack ved Bremen. Journalen er skrevet på hollandsk og bliver oversat til tysk. Indholdet ligner i det store og hele skipperens fortælling. Der bekræftes, at skibet ikke kunne reddes, fordi stormen blev ved med at blæse, da de lå for anker. Man ville have været tvunget til at kappe tovene, hvis de ikke var sprunget af sig selv. Og mandskabet var meget udmattet efter fem døgns hårdt arbejde ved pumperne m.v. Skibsfolket aflægger ed, at de har gjort deres bedste lige til det sidste.

Udover styrmanden mødte der en bådsmand, en tømmermand, en kok, seks matroser og to drenge fra hukkerten ved tinget. Alle bekræfter skipperens og journalens beskrivelser af hvad der var hændt. Hverken skipperen eller styrmanden kunne pålægges skyld i havariet. Men skipperen skulle dømmes til betaling af deres halve hyre. Mandskabet stammer i øvrigt fra hele Nordtyskland fra ost til vest, bortset fra en matros fra Bergen.

Da skipperen accepterer besætningens ønske om hyrebetaling, modtager han villigt tingets tilsvarende dom.

\section{7 - to gange fra Stockholm til England, der aldrig nås}

Den anden stranding skete den 8. december 1747, kun få dage efter hukkerten. Nu drejer det sig om en galiot, kaldet »De Hoffnung «, af 


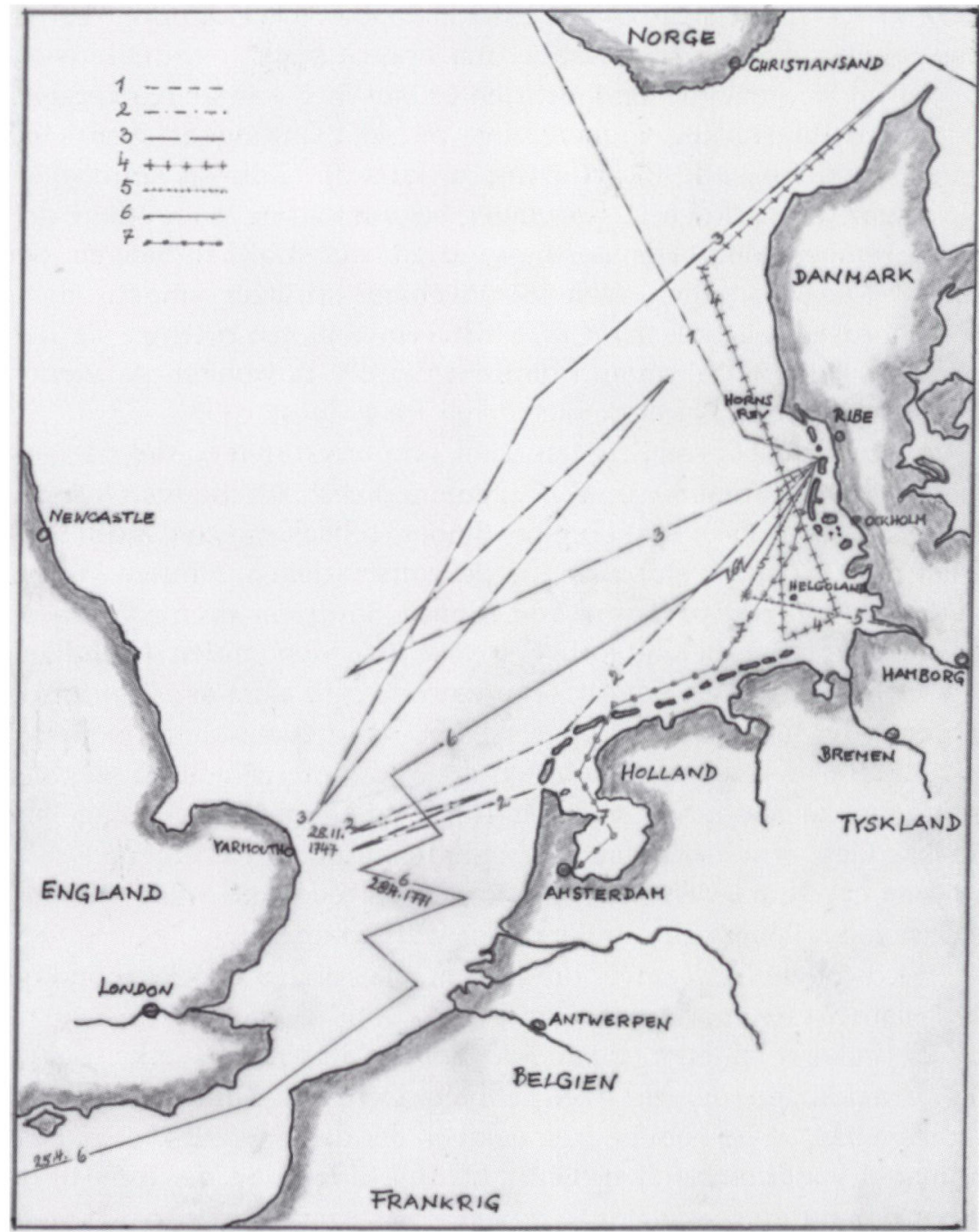

Fig. 6. Kortet viser sejlruten for syv af de skibe, der i 1700-tallet strandede ved Ramø, og som er omtalt nærmere $i$ artiklen.

Stockholm. Skipperen, Oluf Lundius, siger, at de afsejlede derfra den 19. oktober efter Juliansk kalender (»gammel stil«) eller den 30 . oktober efter den »forbedrede« kalender (»nye stil«).

Galioten har en ladning af jern, messing og brædder, bestemt til 
Dublin. Ved strandingen $1 / 2$ mil fra landet taber "De Hoffnung « kahyt, dæk og ror, hvorfor mandskabet må opgive skibet og "retirere " til landet under stor fare. Da journalen er tabt med kahytten, overgiver skipperen en skriftlig indberetning på en blanding af svensk og dansk, med følgende indhold (fig. 6, kurs 3): Galioten kommer til Helsingør toldsted den 11 . november, betaler told og sejler videre den 16. november. Med sydsydøstlig vind går det straks til Skagen, der passeres næste morgen. Den 18. november springer vinden om til nord-nordvest og frisker op til hårdt vejr. Galioten nærmer sig den engelske kyst ved Yarmouth omtrent den 28. november, da vinden atter springer om. Nu er det stormvejr fra sydvest.

Galioten er altså $\mathrm{i}$ samme situation som hukkerten og det på samme tid, men omtrent 80 sømil længere mod vest. Beretningen fortsætter: Fra den engelske kyst kommer skibet »tilbackas igen«, indtil storsejlet mistes i stærk storm den 2. december (dagen, Hinrich Worms sætter sin hukkert på grund ved Rømø). Så driver de med »top og takel« og kommer heldigt forbi det Jyske Rev. Men vinden drejer igen, blæser først fra vestnordvest, senere nord og til sidst øst, hvorfor de atter vender tilbage til den engelske kyst, stadigvæk i hårdt vejr. Det er nu den 6. december, da stormen drejer til vest igen. Store søer slår alt på dækket sønder og sammen. Ingen ild kan tændes. I 8 dage har de ikke fået varm mad. Mandskabet er helt udmattet af fugt og kulde. Fartøjet er efterhånden så læk, at to pumper ikke kan holde det lens. Alle tænker: »wy skulle sunka under wärr fötter«.

Til sidst, den 7. december om natten, taber skibet 2 focksejl og klyversejlet. Næste morgen ses land. Ved 12-tiden er de på 6-8 favns dybde, ankeret falder, men kan ikke holde skibet i den stærke søgang og i brændingen, der går over galioten. Det lykkes under livsfare at sætte en båd ud og komme fri fra skibet, der driver op til kysten. Helt udmattet vader skibsfolket den halve mil til land og når frem til de nærmeste huse.

Styrmanden og to matroser aflægger ed på, at alt er sket som beskrevet. Matroserne bekræfter derudover, at skipperen og styrmanden ikke kunne pålægges nogen som helst forseelse. Alle tre kræver en månedshyre og tilstrækkelige rejsepenge hjem, også for deres fraværende kolleger, to matroser og to drenge, der holder vagt ved vraget. Ladningen og skibsredskaberne er bjærget $\mathrm{i}$ mellemtiden. En af drengene er i øvrigt skipperens søn.

Skipperen bliver dømt til hyrebetaling, og herredsfogden anbefaler 
strandfogden, Peder Andersen Møller, at han omhyggeligt og med "vigilance " skulle hindre skipperne fra begge strandede skibe i at tage noget af det strandede gods. Alt skal bevogtes forsvarligt, indtil et lovligt »inventarium« er lavet, ellers ville Peder Møller blive gjort ansvarlig for skaden.

Derefter står skipper Oluf Lundius frem og kræver forklaring, hvorfor båden og mandskabets klæder er blevet borte. Peder Hansen og Jens Christian Pedersen fik sagerne i forvaring den 8. december om natten, men lod båden med klæderne drive væk. Om måske nogen havde taget klæderne fra båden? Han kræver de to forsømmelige Rømøser dømt til erstatning af klæderne. Deres svar er, at de efter ordre af Peder Møller skulle bjærge båden og klæderne. Og de holdt båden fast i 3 timer, stående i vandet op til deres lår. Men på grund af stormen måtte de lade båden fare, og den drev i land på Hviding forstrand. Så bliver begge af retten »absolveret« med fuld ære.

Den 24. maj 1748 holdes igen ekstrating for disse to strandingssager. Sagen angående galioten "De Hoffnung " er den mest komplicerede. Inventariet er lavet den 6.-11. maj, og også her skal alle vedkommende bekræfte dets rigtighed. Inden man aflægger eden, angives nogle dele, der er solgt $i$ forvejen eller er forblevet $i$ enkelte personers eje inden listens opstilling. Det drejer sig om noget træ, om et anker, noget messing m.v. Skipperen Oluf Lundius spørges, om han har noget at klage over skibsfolkenes behandling på Rømø. Men han siger nej og "takker dennem got ... for deres gode og christelige opførsel ....

$\mathrm{Nu}$ optræder en hr. Ambrosius fra Flensborg. Han er gennem mellemmænd fuldmægtig for en hr. Albert Nisbitt $i$ London. Denne mand ejer alle jernvarer fra skibet. Han havde købt jernet hos Jean $\mathrm{H}$. le Fébre i Stockholm og ville levere det til en John Langley i Dublin. Det drejer sig om 5.161 stænger, 802 skippund, jern. Han foreslår, at varerne efter fortoldning enten sælges eller videretransporteres. Men han bliver skuffet, idet strandforpagterne henviser til deres kontrakt med skipperen og som giver dem halvdelen af ladningens værdi. Hr. Ambrosius minder dem om deres ansvar for materialerne, indtil han har indhentet ejernes accept.

Til sidst kommer skipperen som rederens fuldmægtig og beder om salg af trævarerne på auktion, der dog kun skal publiceres i de nærmeste kirker, for at spare omkostninger.

I oktober 1748 beskæftiger sagen igen tinget på to tingdage, in- 
den den afsluttes. Hr. Ambrosius klager, at han endnu ikke har fået materialerne udleveret og kræver rettens støtte. Det gælder nu også for messing, for hvilket han fremlægger fuldmagt fra ejeren, Jan Anthoni Crop i Amsterdam. Strandforpagterne siger, at varerne vil blive afleveret så snart deres andel er "reguleret«. Den 21. oktober afgøres sagen: efter betaling af alle forpligtelser skal varerne udleveres, trods nogen tvivl $i$ en del af dokumenterne. Der siges ikke, om strandforpagterne beholder en halvdel af materialet eller får deres andel betalt.

\section{8 - »Frimuraren $«$}

Fra tiden 1748-1757 kendes i alt fire strandinger. 1751 straffes én af Nørlandets interessenter, Niels P. With, for ikke at have meldt et lig, han fandt ved siden af en strandet smakke. 1753 strander den hollandske hukkert "Bohmhauer" ved Nørlandet. Den er kommet fra Vestindien og skulle til Amsterdam med kakao- og kaffe-bønner. Ladningen drev til kysten på begge sider af skellet mellem Rømøs to dele. Kakao-bønnerne blev forarbejdet til kager på Sønderlandet og sendt til København. Der må have været et stort bageri i mange hushold!

Den 8. januar 1759 er der igen et ekstrating. Brigantinen »Frimuraren « (fig. 7) fra Göteborg, ført af skipper Oluf Flygare, er strandet den 11. december 1758 ved Nørlandet. Skipperen fortæller »bedrøveligen ", hvad der er sket. Her sammenfattes hans mundtlige beretning med det senere i tingbogen indførte skriftlige indlæg, der blev afgivet af styrmanden, Magnus Niemann af Göteborg, til erstatning for den tabte journal (fig. 6, kurs 4).

"Frimuraren« forlader den svenske kyst den 22. november på vej til Hamborg, hvor ladningen af sild og jern skal losses. Vinden er fra nordøst, og kl. 7 om aftenen ses Skagen fyr. Der følger to dage med godt vejr og liden vind. Derefter begynder stormvejr med ustadig vind og manglende sigt. Der ses hverken fastland eller Helgoland, hvor skibet skal sejle forbi. Brigantinen styres mod Elben, hvor de vil tage en lods, men på grund af tykt vejr må de holde ud efter det åbne hav igen, mens vinden nu kommer fra sydvest. Det er den 4 . december. Det holder på med skiftende vind og dårlig sigtbarhed, indtil den 8. december om natten, da Ostfrisland og Wangeroogs fyr kommer i sigte. Næste dag prajer et skib på vej fra Oldenburg til Holland. Om aftenen frisker vinden op til storm fra vestnordvest, drejer til vest og 


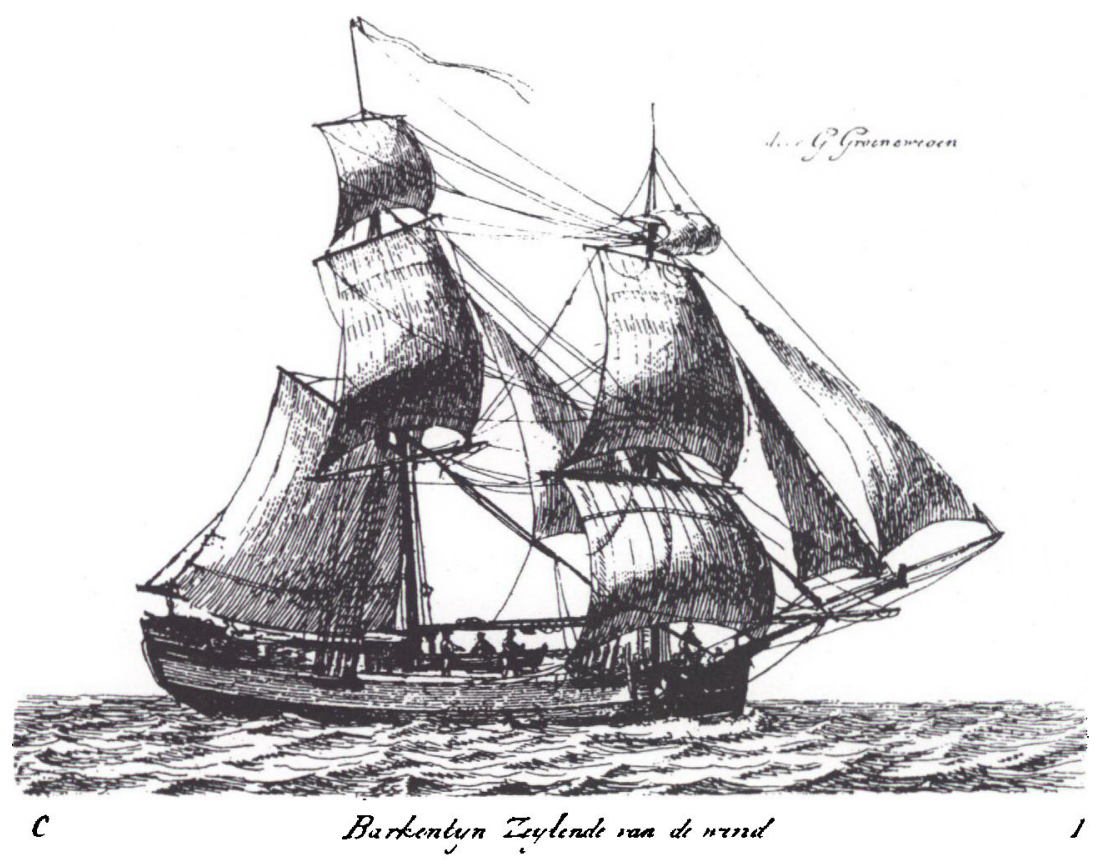

Fig. 7. En brigantine. Gengivet efter C. Groenewegen: Verzameling van vier en tachtig stuks Hollandsche Schepen (Rotterdam 1789).

bliver ved, indtil skibet strander den 11. december kl. 3 om eftermiddagen ved Norlandet, $1 / 2$ mil fra kysten.

Det har været umuligt at "conservere « skibet ved den store og stærke brænding. Hastigt kastes båden ud, en sæk med bøger og journalen smides ind, men da de sidste to matroser endnu er på brigantinen, knuser en »ubeskrivelig hård brænding « båden mod skibet. En matros, Carl Olufsen fra Göteborg, og drengen Johann Beckmann fra Hamborg drukner, mens de andre under livsfare reddes tilbage til skibet. Dér må de 6 overlevende "underkaste sig Hazarten«, indtil de ved lavvande kan vade $i$ land. De bliver alle vel optagen, og skipperen kan sørge for at få ladningen bjærget. Han slutter »frivilligen « en kontrakt med de to underforpagtere Anders Pedersen Møller og Jesper Mathisen, der snarest bringer alt under "Fordæk " hos A. P. Møller.

Det er 425 tønder sild og 409 diverse stænger jern; 6 stænger er gået tabt. Desuden er af skibsredskaberne reddet 3 ankre, løbende og stående tovværk m.v. Skibsfolket bekræfter det hele under ed og får, 
som sædvanligt, deres krav på en månedshyre og rejsepenge opfyldt. Dommeren befaler, at der flittigt skal ledes efter de druknedes lig og sørges for deres kristelige jordefærd. Omkostningerne pålægges skipperen, ligeså for betaling af "mesteren ", der har "cureret og læget« skibsfolkene. Skipperen kræver en hurtig vurdering af materialerne og snarest salg af vraget. Efter ladningen at dømme må skibet have været på omkring 40 kommercelæster.

Allerede den 5. februar bliver sagen videreforhandlet og afsluttet. Den "fahrende Commandeur fra Hamburg « Hans Tønnis optræder som fuldmægtig for ladningens "Commissionairs", Salomon Rosen og Frantz J. Hagelberg fra Hamborg. Hans Hansen Tønnis (d.æ.) er en af tidens bedst kendte kommandører, Rosen repræsenterer en af Hamborgs førende handels- og rederfamilier. Hans Tønnis fremviser to "Connossementer", hvorefter S. Rosen er ejer af sildetønderne, markeret "J. C." (afsenderens initialer), Hagelberg ejer af jernet, i alt 64 skpd. Han kræver udlevering efter betaling af bjærgelønnen, told og rettens gebyr.

Skipperen, Oluf Flygare, henviser til en kontrakt, han har sluttet med leverandørerne i Göteborg. Ifølge den får han 1.089 rigsdaler fragt for silden og 128 mark for jernet plus $2 / 3$ af omkostningerne, der er 18 rd., for hele rejsen. Sørettens bestemmelser udlægges sådan, at han kan kræve betaling i forhold til vejstrækningen til strandingen, der er omtrent $2 / 3$ af vejen til Hamborg. Varerne må ikke afleveres, før betalingen er sikret. Hans Tønnis er indforstået med dette krav.

Strandforpagternes kontrakt med skipperen lyder på en bjærgeløn, der svarer til 3/8 af ladningens og redskabernes retmæssigt takserede værdi. Derudover fremlægger Anders Pedersen Møller en revers, hvorefter skipperen har forpligtet sig til at betale $10 \mathrm{rd}$. pr. måned for pakhuset. Efter søretten skulle befragteren svare de forpligtelser, en skipper per kontrakt har indgået efter en stranding. Derfor skulle alt betales før varernes udlevering.

$\mathrm{Nu}$ står spørgsmålet til diskussion, om befragterne kan være ansvarlige for skippernes kontrakter. Skipperen siger, at han ikke kunne risikere tabet af hele ladningen og derfor måtte kontrahere som gjort. Hans Tønnis tilbyder $1 / 3$ bjærgeløn istedet for $3 / 8$, og resten reserveret indtil rettens afgørelse. Også angående pakhusets lejemål vil han vente derpå. Strandforpagterne, alle tilstedeværende, svarer, at ingen ville have bjærget varerne til en lavere pris. Hans Tønnis skulle vide det, da han var på øen i denne tid. 
Dommen fra den "Königl. würkliche Cantzeley-Rath und Hardesvoigt in Hvidding-Harde, Georg Christian Hoffmann zu Roost « slår fast, at ladningens sande ejere er befragterne i Sverige. Hans Tønnis er deres lovlige fuldmægtig. Derfor skulle ladningen afleveres til ham efter betaling af alle skipperens og forpagternes velberettigede fordringer, rettens gebyr såvel som $1 \%$ "pro transita istedet for told. Alle parter accepterer dommen.

For Hans Tønnis og klienterne er der ikke meget tilovers: Ladningen er vurderet til 1.123 rigsdaler. Bjærgerne får 3/8 deraf, 421 rd. plus 20 rd. pakhusleje og staten henved 50 rd. Fragten, aftalt før rejsen, er forbavsende høj, på samme niveau som varernes værdi. I Hamborg må salgsværdien have været mindst tre gange indkøbsprisen hhv. vurderingen. Ellers ville købmands-folket ikke have godkendt forretningen. Hvordan de har delt skaden mellem sig, vides ikke.

\section{0 liter fransk vin}

En sag på Sønderlandet angående 11 oksehoveder (à 217 liter) vin, fundet i marts 1760, kommer for Ballum tinget, der dengang samles i Niels Pedersen Ålheits hus på Rømø. List-tolderen Abildgaard klager mod »en del egennøttige, selvraadige samt domdristige mennesker«, hvormed han mener præstens to sønner Christian og Rasmus Neve, hvoraf den sidste samme år blev øens kapellan. Udover de to stævnes 4 mænd og 5 kvinder, deriblandt præstegårdens tre tjenestepiger. Retten må beskæftige sig tre dage med sagen, da hvert vidne får stillet 10 spørgsmål om hændelsen.

Én af tjenestepigerne var ved stranden for at søge strandgods på Christian Neves ordre. To piger bevidner, at vinen blev afleveret til præstesønnerne. To skippere har transporteret oksehovederne til Rislum, et lossested ved Kromose. En kvinde, Karen Peders, datter af den tidligere Rømø-matador Peder Holm og gift med kommandøren Peder Andersen, boende i Kromose, nægter at komme til tinget. Hun straffes med $10 \mathrm{rd}$. for hver dag, hun ikke møder op. Den 3. dag kommer hun alligevel. Hun skulle udtale sig, om hun eller hendes hushold var behjælpelige med folk, vogn og lagerplads. Hendes svar er ligeud og enkelt: "Nej!«

Christian Neve påstår at være fuldmægtig for Sønderlandets strand under hovedforpagteren Morten Spangsberg, men det er lidt uklart. 
Landfoged Mathisen på Sild og tolderen Abildgaard anfører derimod at have givet strandfuldmagt til kommandør Christen Jensen og to andre fra Sønderlandet, men det har de gjort på eget ansvar. Begge parter strider hårdt om sagen, der til sidst afgøres salomonisk: Christen Jensen skal "forvalte " stranden og gemme de 11 oksehoveder, indtil Christian Neve kan fremvise en gyldig fuldmagt.

Kun få dage senere bliver situationen helt anderledes. Ejeren af vinen melder sig! Det er en købmand fra Bremen, der ventede 583 oksehoveder (over 130.000 liter) fransk vin med skipper Erich Rüters skib fra Vegesack. Men skibet forliste ved Helgoland den 16.2.1760. Fadene er mærket, hvorfor i alt 80 ved List, Rømø, Ballum og Brøns strandede oksehoveder kan identificeres som købmandens eje. Efter betaling af told, gebyrer og bjærgeløn får han dem udleveret.

\section{0 - et stormvejrs-efterår}

Den 20. november 1760 holdes et Nørlandsting på Rømø i Christen Erichsen Bagers hus i Kongsmark. Såvel i oktober som i november har der været strandinger ved Nørlandet. Rettens betjente er kommet til Rømø for to dage siden for at undersøge sagerne. Samme strandforpagtere som i 1758 står for retten og vidner. Storm og uvejr har uafbrudt holdt sig siden Michelsdagen (29. september) og forårsaget mange havarier til søs. En del skibsfolk er reddet, en del er drevet døde i land og "hæderligt « begravet på øen. Den 21. oktober drev en tjalk eller snekke "bunden udi vejret « ind på stranden uden mennesker, hverken levende eller døde. Vraget var læsset med norsk træ, der er bjærget og bragt til taksering. Masten, sejl, tovværk og anker var borte. Dagen efter tinget skal nogle mænd fra Kongsmark liste træet op og vurdere det.

Den 23. oktober fandtes en galiot på stranden. Agterskibet var borte, ligeså mast og sejl. Omtrent halvdelen af ladningen, savblokker og bjælker, var der endnu, men kunne ikke bjærges. Først nu er skibet drevet så langt op på stranden, at det kan lykkes. Mennesker var der ikke ved vraget, hverken levende eller døde.

Den 4. november, kl. 5 om morgenen, ankom en lille engelsk 3mast fregat, fransk-bygget, ved stranden. Fregatten lå på siden, den eneste resterende mast, besanmasten, i vandet. I masttoppen sad en del overlevende, men på grund af storm og brænding kunne de ikke bjærges før kl. 2 om natten. Dagen efter har søen slået fregatten helt i stykker, og de sørgelige rester drev til havs. 
Angående søfolkenes skæbne er der lidt forskellige udsagn, måske som følge af sprogproblemet. Englænderne kan hverken dansk eller tysk. Svend Steffensen, en tilflyttet sømand og bonde fra Kongsmark, er indsat som tolk. Når man sammenfatter forpagternes og de reddedes oplysninger, må der været sket følgende (fig. 6, kurs 5):

Fregatten "Johanna Elisabeth « forlader Hamborg den 24. oktober på vej til Newcastle med ballast. Kaptajnen er John Smert fra Newcastle, skipper eller styrmand Thomas Davidson. Ellers er der 10 matroser ombord. Efter 5 dage i Cuxhaven sejler skibet den 1. november af sted ved sydlig vind og "sejlbar vejr«. Men dagen efter bliver det til vestvind med stormbyger. Den 3 . november møder de en enmastet galiot fra Stettin, ladet med rug og hvede fra Danzig til Hamborg. Skibet er ved at synke. Englænderne redder hele mandskabet og en passager og har nu i alt 21 mænd ombord. De søger læ bag Helgoland, men det mislykkes. Stormen tager til, meget vand kommer ind, og man er nødt til at kappe stormasten den 4 . november $\mathrm{kl}$. 4 om morgenen. Kort efter støder fregatten på grund ved Rømø og kæntrer. 6 englændere og 8 tyskere drukner. Om aftenen svømmer 3 engelske søfolk til kysten på en gammel rå. Hele natten ligger de i klitterne, og én dør af kulde og svaghed. Kaptajnen bindes på et stykke vrag med fødderne, men han når stranden som lig, klæderne slået sønder af søen. De sidste 3 mænd, deraf skipperen og en tysker, reddes tidligt næste morgen med en båd.

Alle er naturligvis helt »elendige af kuld og nød « og bliver forsørget med mad og alt nødvendigt, også »hjulpet til helbred, såvidt muligt«. De fundne druknede søfolk bliver klædet, lagt i kiste og jordet på Rømø kirkegård. Passageren, en ung købmand fra Hamborg, blev ikke fundet. Skipper Thomas Davidson og de andre overlevende roser forpagterne og øens øvrige befolkning for deres hjælpsomhed og beder om klæder og rejsepenge hjem, betalt af vragets rester. Det tilstås af forpagterne, og skipperen får $10 \mathrm{rd}$., de andre $5 \mathrm{rd}$. som forskud. Dermed er denne dramatiske sag afsluttet for retten.

\section{1 - nye strandinteressenter bliver snydt}

I 1769, efter at Haderslev-borgmesteren Matthias Mussmann havde haft forpagtningen af Nørlandet i en årrække, overtager et konsortium af 8 mænd hovedstrandretten på Rømø Nørland for $\mathbf{4 0 0}$ mark (133 rd) årlig pagt. Fra Rømø er det de to landfogeder Hans Peter 
Hansen fra Toftum (i dag Nationalmuseets Kommandørgård) og Peder Pedersen Holm fra Tagholm, den kendte Peder Holms søn. Derudover Hans Peter Hansens stedsøn Thade Harckens og fra Sønderlandet skipperen Jørgen Nielsen. Fra fastlandet deltager 4 mænd fra Holmgård, Skærbæk, Barsbøl og Arrild. Den sidste, Niels Winther, bliver senere Nørlandets landfoged og stamfader til øens Wintherslægt.

Den første stranding i deres tid sker i maj 1771, et usædvanligt tidspunkt. Og sagen ender skuffende for forpagterne. I begyndelsen løber dog alt som det plejer. Der holdes ekstrating den 15. maj på Rømø. En hukkert "Emanuel «, $60 \mathrm{kl}$. stor, hjemmehørende i Visby/ Gotland, er strandet den 11. maj ved midnat. Skibet var på vej fra Nantes til Hamborg og Altona med mange forskellige eksotiske købmandsvarer som kaffebønner, sukker, kattun, gedeskind, indigo, sirup, flintesten m.v., bestemt til en række købmænd. Skipperen, Friderich Ahlberg, fortæller detaljeret om hele rejsen (fig. 6, kurs 6) indtil strandingen ved Rømø.

Da skibet var gået på grund, lod han skyde med kanonen tre gange for at råbe om hjælp, men forst om morgenen kommer en båd fra Mandø, mens en storm fra øst er begyndt at blæse. Manden fra Mandø bringer besætningen og det tørre gods fra kahytten til Rømø og dér til Hans Peter Hansens hus i Toftum.

Efter denne beretning roser Friderich Ahlberg såvel mandskabet som bjærgere og befolkning for deres indsats og kræver, som sædvanligt, ladningen og redskaberne bjærget og vel konserveret, men ikke udleveret, inden han har faet fragten betalt. En kontrakt oprettes med forpagterne. Mandskabet, 7 mænd fra Gotland, bekræfter alt og kræver en månedshyre såvel som rejsepenge, hvad de får tilsagt. Derved er alle tilfredse, men sagen langt fra at være nået til en ende.

Den 27. maj mødes en hr. Goverts fra Hamborg som fuldmægtig for ladningens ejere med strandinteressenterne på tinge. Goverts mener, at $1 / 3$ af ladningens værdi som bjærgeløn er for meget; en stor del af varerne er bjærget af to Mandø-både. I øvrigt kræver han udlevering mod kaution. Rettens afgørelse lyder på en kaution for bjærgelønnen, dvs. 1/3 af hele vareværdien. Den 10. juni leverer Tønderborgmesteren Mathias Tychsen denne kaution for varernes ejere. Hans Peter Hansens fordring for pakhusleje og øvrige omkostninger bliver forst afvist, men til sidst tilgodeset med et forskud på bjærgelønnen, stort $400 \mathrm{rd}$. Så får Hamborgs og Altonas købmænd deres 
varer. Men forpagterne kun et stykke papir for deres resterende penge.

Efter en hel række forhandlinger falder dommen den 1. maj 1772: der skal betales den kontraherede tredjedel af varernes takserede værdi plus rente såvel som alle omkostninger. Men begge kontrahenter appellerer mod dommen, forpagterne sandsynligvis, fordi den ikke indeholder muligheden for at anvende rettens tvangsmiddel. Og de får heller ikke deres penge. Sagen findes over flere år $\mathrm{i}$ tingbogen, borgmester Tychsen er forlængst død, og der er ikke noget mere at hente.

\section{2 - et lille kystskib med mange varer}

Den 30. september 1772 behandles strandingen af en snigge (fig. 8), "de jonge Jan ", $91 / 2 \mathrm{kl}$., et mindre, tomastet skib til kystsejlads. Det er

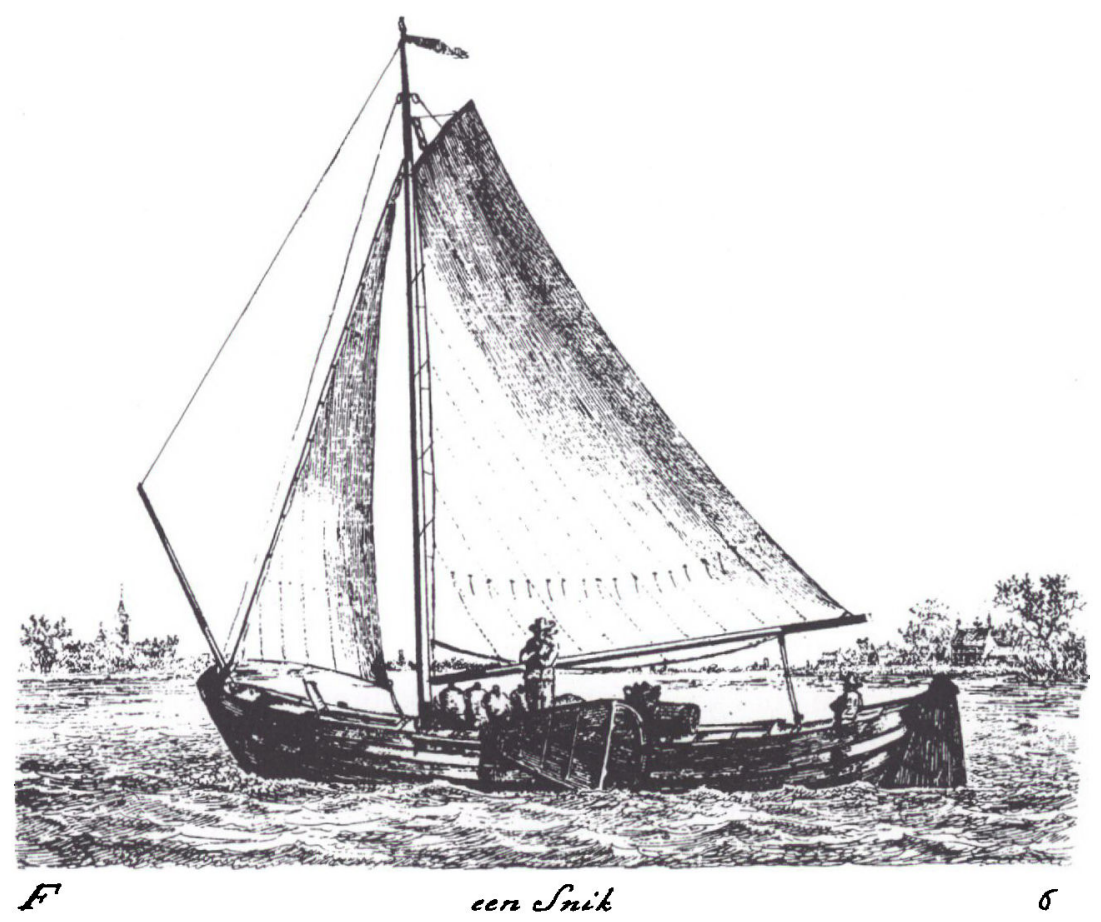

Fig. 8. En snigge. Skibet omtalt i teksten havde også besanmast, og var altså tomastet. Gengivet efter C. Groenewegen: Verzameling van vier en tachtig stuks Hollandsche Schepen (Rotterdam 1789). 
ført af skipper Dirk Boysen fra Amrom. Han har i Amsterdam indtaget mange forskellige købmandsvarer til købmænd i Flensborg og Bredsted. Ombord er også en passager på vej hjem til Amrom. Varerne skal bringes til Ockholm ved kysten vest for Bredsted. Skipperen fortæller meget livligt om oplevelserne til søs (fig. 6, kurs 7):

Den 21. september forlades Amsterdam. To dage sejler skibet på Zuidersøen nordpå, om natten dog liggende for anker. I selskab med to andre skibe kommer de ud i Nordsøen ved Ammerland, hvor der blæser en stiv kuling. Klyver-, fock- og topsejl tages ned. Skipperen vil gerne lægge sig i læ i Emsmundingen, men det bliver for mørkt. Så sejler de for vinden, kun med klyversejl, mod nordvest. Skibet er tæt og de føler sig vel. Men vinden drejer efterhånden mod sydøst, og de må sejle op mod vinden for ikke at komme for langt fra kysten. Det lykkes ikke trods alle slags sejlmanøvrer. Skipperen prøver at komme til Helgoland og lægge sig i læ dér. Der er nu storm fra syd og dårlig sigt, tykt vejr med regn. Hele dagen den 23. skønner skipperen at være mellem Norderney og Helgoland. Den 24. om morgenen formoder han at have nærmet sig denne $ø$. Skibet er endnu tæt, men en kastebold for søerne. Kompasset springer 5 til 6 linier frem og tilbage, den lille snigge er mere under end over vandet, og den er næsten ikke til at holde styr på. Hen imod aften ses pludseligt den Røde Klippe på Sild, og mandskabet, ja sågar passageren, gør alt for at holde skibet fra landet og sejle nordpå til Lister Dyb. Søerne går over skibet til besanmastens halve højde, og alle tre mænd er nødt til at stå ved roret. Om natten når de dybet, men det var ikke muligt at lægge kursen østpå ind ad dybet. Skibet støder istedetfor på Rømø Nørlandets strand. Alle forsøg på at vende skibet over stag mislykkes. Så strander skibet, og mandskabet holder sig ved masten, indtil de kan nå kysten ved lavvande. Alle bliver reddet. Skibet er endnu tæt, men da ladningen skal hentes, er lugerne slået i stykker og en del varer fordærvet.

Syv uger senere kom sagen for tinget. 13 købmænd hhv. deres fuldmægtige møder frem og făr efter den fornødne legitimation lov til at hente de reddede varer efter betaling af alle gebyrer, fragt og forpagternes andel. Det drejer sig om mange fade, kasser og pakker, betegnet med navn eller mærke, indeholdende alle mulige slags varer (se fig. 9). Det er forbavsende, hvad der blev handlet med fra Holland til Slesvig. Desværre kender vi ikke værdien af det lille skibs ladning, men den var ganske sikkert ikke ringe. 


\begin{tabular}{|c|c|c|c|}
\hline Kebmandens navn & Bopæ! & Mærker & Varer \\
\hline Hans Peler Laurup & Bredsted & 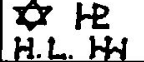 & Bleghvidt, lim, benolie, eddike, vin, tobak \\
\hline Hans Malhiesen Meller & Bredsted & HR H.M. & Mosel-vin. kurvand (sur brondvand i krukker) \\
\hline Henning Peter Henningsen & Flensborg & & Tobak \\
\hline Paul Hor Mathiesen & Bredsted & $F M$ & Hagl \\
\hline Franz von Palen & (p.a.Bredsled) & F.V.P. & Peber \\
\hline Hans Lorenz Moller & Bredsled & I.N. & $\begin{array}{l}\text { Rapolie, sem, papir, pulver, hagl, pibe ler, } \\
\text { blyhvidt }\end{array}$ \\
\hline Bendix Hansen Schmidt & Bredsted & H.B.S. & Cochenille, Jarve \\
\hline Carsten Sleensen & Bredsted & & $\begin{array}{l}\text { Pulver, hagl. papir, ost. laks.leg, anis, peber. } \\
\text { allehànde, olie, eddike, rapolie, hør, blyhvidt }\end{array}$ \\
\hline Caspar Hinrich Loh & Bredsted & $\begin{array}{l}\text { o.H.o. } \\
\text { o.V.a. }\end{array}$ & $\begin{array}{l}\text { Pulver, hagl, bomuldsgarn, sem, peber, allehánde, } \\
\text { ingelær. lakrids, kaneel. kalle bonner. muskat. } \\
\text { blommer, błá farve }\end{array}$ \\
\hline Jacob Nonsen & Lindholm ") & I.N. & Benolie, brændevin \\
\hline Marquard Jacobsen & Flensborg *) & & Tobak \\
\hline Hans Hansen & Flensborg & & Piber, rapolie \\
\hline Friedrich Christian Knigge & Flensborg ") & 郝 F.C.K. & Sem, flagdug \\
\hline
\end{tabular}

1) Var selv tilstede ved tinget, mens der kom en fuldmægtig for de andre købmand

Fig. 9. Kabmandsvarer på sniggen "De jonge Jan «, strandet på vej fra Amsterdam til Ockholm 1772.

\section{Strandrøveri eller ej?}

Af 1700-tallets sidste seks kendte strandinger skal her kun fortælles om en sag, der kommer for tinget i februar 1778 på grund af landfogedens klage over et strandrøveri. Sagen kaster lidt lys over øboernes holdning til strandgods og myndigheder. Blandt »strandrøverne« er to af Nørlandets velhavende bønder og skippere fra Juvre. Jørgen Nielsen Bleeg kendes som kaptajn på »Joffrou Anna«, 38 kl., Christen Pedersen på »Westmannø«, 48 kl., begge skibe hjemmehørende i København. Den tredie mand er smeden fra Toftum.

Den første tingdag beretter landfogedens stedsøn Thade Harckens (30 år): Den 26. november 1777 er han med en vogn og tre andre mænd kørt ud til stranden for at se på et delvrag, fundet dagen før. Dér træffes Jørgen Nielsen Bleeg fra Juvre, 2-3 bøsseskud fra vraget, foregivende at søge tang. Han påstår at have lov til at være der, da stranden er kongens, hvor alle »Unterthanen« har samme ret at opholde sig. Derefter træffes Christen Hansen Smed fra Toftum og Chri- 
sten Pedersen fra Juvre, den første med et stykke jern fra vragets ror. Et lignende stykke, fundet næste dag, formodes at være kastet bort af Christen Pedersen inden han blev opdaget. Thade Harckens siger til dem, at de vist er kommet med økse og brækjern (hvad smeden har i hånden) for at gå på rov på kongens strand. Snart efter er de i skænderi, og Jørgen Bleeg opfordrer Thade Harckens til at komme ned fra vognen for at få en dragt prygl. Dagen efter skal Christen Smed være kommet til landfogeden og have tilbudt nogle banco-sedler mod at glemme sagen.

Jørgen Bleeg (34 år) og Christen Smed (31 år) giver efter gentagen opfordring deres version af historien. Thade Harckens skal være kørt efter Jørgen Bleeg »i galop« og have sagt, at han nu vidste, hvem strandrøverne fra Juvre var. Det gjorde Jørgen Bleeg vred, og han svarer: "Du snavbasse vil vel få mig trække dig fra vognen og slå dig over buklen«! Derefter går han hjem. Christen Smed siger at han ville tjene en bjærgeløn og at han havde mødt Christen Pedersen ved stranden. I fælleskab brækkes to stykker jern fra vraget, men det ene tabes igen pga. vægten. Næste dag går han til landfogeden, afleverer jernet og tilbyder noget til de fattige, ikke »til at persuadere ham«.

Christen Pedersen (30 år), der er på Grønlandsrejse, forhøres i oktober samme år. Han ville også tjene nogen bjærgeløn, dvs. aflevere jernet, han har brækket fra vraget. Men højvandet kom allerede ind $\mathrm{i}$ støvlerne, og han måtte smide jernet for at redde sit liv. Der findes ingen dom $i$ tingbøgerne, og heldigvis blev en kongelig forordning om sådanne sager forst udstedt 8 år senere: derefter skulle de tre Rømøser "strax pågribes og hensættes i Forvaring samt ... dømmes i Arbejde i nærmeste Tugthus på nogle År«!« 


\section{Sammenfatning}

I alt 28 strandinger lykkedes det at fastslå i kildematerialet - tingbøgerne og toldregnskaberne. Disse skibe udgør kun et ganske lille udsnit af den flåde af skibe, som i periodens løb passerede forbi Rømø. Alligevel tegner ladningerne fra disse strandinger et billede af de handelsstrømme mellem Nord-, Øst-, Vest- og Sydeuropa, som gik forbi øen.

Fra nord gik en stadig trafik med træ, træprodukter, skind og tran helt fra ishavet og fra Norge til landene omkring Nordsøen. Fra de østlige Østersølande kom skibe med træ, fra Sverige bearbejdede træprodukter, jern og messing til samme område. I omvendt retning var det oftest ballast, men også kul fra England eller fødevarer, man sejlede med. Sydfra kom først og fremmest eksotiske varer til Nordsøområdet. Ofte var de losset til mindre skibe i en af områdets store havne, især Amsterdam og Hamborg.

Før 1700-tallet lå strandingssagerne endnu i statens hænder. Derefter blev det almindeligt at bortforpagte strandrettighederne til private. Det krævede gennemførelse af klare retsforhold mellem alle parter, der var indblandet $i$ sådan en sag. Den gamle regel, at bjærgerne skulle have en trediedel af det bjærgedes værdi, forblev i kraft, såfremt parterne ikke havde aftalt andre betingelser. Forhandling af strandsagerne ved retten skulle sikre, at mulige forsømmelser fra skipperens side blev afsløret, og at mandskabet fik deres rette hyreandel udbetalt samt evt. penge til hjemrejsen. Ejendomsretten til varerne skulle dokumenteres med beviser, fordi aftalerne mellem købmænd, redere og skipper kunne være meget forskellige. Ofte blev en del af ladningen handlet og transporteret for skipperens egen regning, ligesom de for det meste var medredere. Omkostningerne ved den komplicerede retsbehandling måtte udredes af det bjærgedes værdi. Men til gengæld fik især varernes ejere en større retssikkerhed.

Strandingsgodset repræsenterede ofte en betydelig værdi, og det var derfor fristende for befolkningen at prøve at hente sig en ekstra fordel. Ikke uden grund måtte retten derfor pr. rutine spørge efter eventuelt ikke meldte varer eller genstande. Og det var vistnok en "sport« for mange øboere at gå ud til stranden efter en storm og se, hvad der kunne hentes.

Kildematerialet tillader kun at tegne et ret så nogternt billede af det hændte. Søfolkenes ofte barske oplevelser, alt hvad de måtte udholde 


\begin{tabular}{|c|c|c|c|c|c|}
\hline Lbonr. & \multicolumn{2}{|l|}{ Dato og Sied } & \multicolumn{2}{|c|}{ Skibatype, navn og aterrelac (kommezzlester) } & \multirow{2}{*}{ Pa vej fra-til } \\
\hline 1 & 10.11 .1711 & SR & & & \\
\hline 2 & 01.1716 & NR & Pregat & "Princesse" & \\
\hline 3 & 26.09 .1717 & NR & & & \\
\hline 4 & 121721 & SR & & & \\
\hline 5 & 1742 & SR & Smakke & "Adam und Eva" & \\
\hline 6 & 20.10 .1745 & NR & & "Het witte Hart" & Archangelak-Hamborg \\
\hline 7 & 02.121747 & NR & Hukkert & "Chrietiana" & Amstendam-Bordeaux \\
\hline 8 & 08.12 .1747 & NR & Galiot & "De Hoffnung" & Stockholm-Dublin \\
\hline 9 & 12.09 .1751 & NR & Smakke & & Norge-Sild \\
\hline 10 & 25.12 .1752 & NR & Hulkkert & "Botumbaver Galley" & Vestindien-Amsterdam \\
\hline 11 & 07.10 .1756 & NR & Koff & "De jonge Liacheta" & Bondeaux-Hamborg \\
\hline 12 & 10.1756 & NR & & & \\
\hline 13 & 11.121758 & NR & Brigantine & "Primuraren" & Gorteborg-Hamborg \\
\hline 14 & 21.10 .1760 & NR & TjalkS Snekk & & Norge-? \\
\hline 15 & 23.10 .1760 & NR & Galiot & "Die beiden geliebten Brader" & Stettin-Holland \\
\hline 16 & 24.10 .1760 & SR & Koff & & \\
\hline 17 & 04.11 .1760 & NR & Pregat & "Johanna Elisabeth" & Hamborg-Newcastle \\
\hline 18 & 16.10 .1765 & NR & Smakke & "Glaube, Liebe, Hoffnung" 12 kJ & Norge-Fatx \\
\hline 19 & 06.10 .1767 & NR & Brigantine & "De Nelly" & Goteborg-London \\
\hline 20 & 10.1767 & NR & Smakke & "De jonge Douwe" & Norge-Holland \\
\hline 21 & 10.1767 & SR & & & \\
\hline $\boldsymbol{n}$ & 11.05 .1771 & NR & Hukkert & "Emanuel" & Nantes-Hamborg \\
\hline 23 & 25.09 .1772 & NR & Srigge & "De jonge Jan" & Amsterdam-Ockbolm \\
\hline 24 & 12.09 .1773 & $\mathbf{N R}$ & Galeane & "Catharina" & Kalmar-Amsterdam \\
\hline 25 & 25.11 .1777 & NR & & & \\
\hline $\mathbf{x}$ & 21.10 .1782 & NR & Brigantine & "Jomfiu Henrica" & Bergen-Amsterdam \\
\hline$n$ & 29.09 .1788 & NR & & "Prau Mette" & Makkum-T ønder \\
\hline 28 & 11.12 .1792 & $\mathbf{N R}$ & & "De Vrouw Sabina" & Norge-Amsterdam \\
\hline
\end{tabular}

Tabelbilag 1. Kendte strandinger ved Romo $i$ 1700-tallet. Strandinger af lose varer er ikke medtaget. Bemærkninger: 1) I parentes: deraf druknede. 2) Et lig fundet ved siden af vraget (Haderslev Amtsregnskab, bøde for ikke meldt lig). 3) J. Laß: Sammelung einiger Husumischen Nachrichten, Flensborg 1750, 1. Forts., Anhg., s. 7. 4) TBB: Kakaobønnerne bliver forarbejdet på Sønderlandet, hvor en del også var drevet 


\begin{tabular}{|c|c|c|c|c|}
\hline Hjemsted & Manduk 1) & Ladring & Kaptajn & Kilde \\
\hline Fohr & ? (?) & Trze & Broder Pedersen & LTR \\
\hline \multirow[t]{2}{*}{ Spanien } & ca.70 (?) & Orlogsskib & Lieut. Bredall & TBB \\
\hline & $?(7)$ & Ballast & & TBB, THH \\
\hline Skotland & $?(7)$ & Sild & & LTR, TBB \\
\hline Rendeborg & $?(?)$ & Enebsertracendevin m.v. & Claus Reien & LTR \\
\hline Hamborg & $?$ & Tran, tixre, akind & Hans J. Dahler & LTR, THH \\
\hline Hamborg & 13 & Ballast & Hinrich Worm: & THH \\
\hline Stockholm & 8 & Trxa, jem, messing & Oluf Lundius & LTR, THH \\
\hline Sild & $7(?) 2)$ & Tra & Anden Peter Thiesen & LTR, Hus 3) \\
\hline Amstendam & $?(?)$ & Kalcaobronner m.v. 4) & Frane Witte & LTR, TBB,THH \\
\hline \multirow[t]{2}{*}{ Vestfrisland } & $?(?)$ & Puderoukker, kaffe & Seybold Typehes de Welde & LTR \\
\hline & $?(?)$ & Tra & & LTR 5) \\
\hline \multirow[t]{2}{*}{ Gorteborg } & $8(2)$ & Sild, jem & Oluf Plygare & LTR, THH \\
\hline & $7(?)$ & Tres & & LTR,THH S) \\
\hline \multirow[t]{2}{*}{ Føhx } & $7(?) 6)$ & Tra & Lorentz Poulsen & LTR, THH \\
\hline & $?(?)$ & Tre & & LTR 5) \\
\hline Newcastle & $12+9(16) 7)$ & Ballagt & John Smert & THH \\
\hline Fohr & 3 & Tre & Hans Chr. Brodersen & LTR, THH \\
\hline Newcastle & 5 & Trex, jem & Thomas Brown & LTR, THH \\
\hline \multirow[t]{2}{*}{ Groningen } & $?(?)$ & Tra & Martin Douwe & LTR \\
\hline & $?(?)$ & & & LTR 5) \\
\hline Gotland & 8 & Kebmandavarer & Friderich Ahlberg & LTR, THH \\
\hline Amnum & 3 & Kobmandsvarer & Dirk Boysen & THH \\
\hline \multirow[t]{2}{*}{ Malmø } & $6(1)$ & Tjare, beg, kJaptre & Ander Pyk & ТНH \\
\hline & $?(7)$ & & & ТНH 8) \\
\hline Bergen & 7 & Tran, fisk, akind & Mada Dichichsen Troefast & ТнН \\
\hline \multirow[t]{2}{*}{ Emmeriev } & 2 & Kalk, tagsten & Hans Grooth & THH \\
\hline & 14 & $\operatorname{Tr}$ & Broder Mellefisen d.j. & THH \\
\hline
\end{tabular}

til lands; THH: Strandingen næones $i$ en sag $i$ 1772. 5) Vraget fundet uden folk, bunden $i$ vejret. 6) Vraget fundet uden mandskab, men skipperen melder sig senere ved tinget. 7) Fregatten har overtaget skibbrudne søfolk undervejs. 8) Der næones kun selve vraget $i$ en strandroverisag. 
dag og nat, sommer og vinter kommer kun sjældent direkte frem. Alligevel skinner det igennem mangen strandingsberetning. Med lidt fantasi kan man nok ane dagligdagens strabadser for mandskabet. I forhold til vore dages fartøjer var datidens skibe at ligne med nøddeskaller på et ofte ubønhørligt hav. For enkelte af dem endte sejladsen brat på Rømøs kyst.

\section{HENVISNINVER}

1. Ballum Birks tingboger, Landsarkivet i Aabenraa.

2. Hviding Herreds tingbøger, Landsarkivet i Aabenraa.

3. Toldregnskaber List og Amrum, Rigsarkivet i København.

4. B. Bundesens optegnelser ang. stran- dinger ved Romø, privat eje. En del af Bundesens arkiv findes $i$ landsarkivet i Aabenraa.

5. W. u. W. Fey, H. J. Stöver: Strandungen vor Sylt, Husum 1979.

6. Carstens u. Falck (Hrsg.): Staatsbürgerliches Magazin Bd. IV, Schleswig 1824 s. 666. 